\title{
Chromosome 17
}

National Cancer Institute

\section{Source}

National Cancer Institute. Chromosome 17. NCI Thesaurus. Code C13212.

The designation for each member of the seventeenth largest human autosomal chromosome pair. Chromosome 17 spans more than 81 million base pairs and represents between 2.5 and 3\% of the total DNA in normal diploid cells. 